\title{
Podpora kognitivních procesů nadaných žáků v konstruktivistickém pojetí
}

\author{
Support for cognitive processes of gifted pupils in constructivist approach \\ Jana Škrabánková
}

\begin{abstract}
Abstrakt: Podpora kognitivních procesů nadaných žáků úzce souvisí s kvalitou pedagogické práce učitelů v praxi a je determinována úrovní pregraduální př́pravy budoucích učitelů. Ve svém prŕspěvku se zaměřuji zejména na vymezení rozdílů ve způsobech učení se nadaných žáků a způsobech učení se tradiční žákovské populace a také na analýzu způsobů učení se nadaných žáků s ohledem na konstruktivistické trendy v pedagogice. Spolu s ostatními činiteli celá tato poznávací cesta končí vytvořením teorie vzdělávání nadaných žáků pro přenos do praxe. Modernizace učebních postupů může být založena nejen na zdokonalování stávajících strategií, ale také na zcela nových, ve světě již popsaných integrálních mapách jednotlivých disciplín. Při konstruování předloženého modelu jsem se snažila naplnit vizi, že nová sdělení mají být předávána systematicky. Mají umožňovat kladení nových výzkumných otázek a formulování takových hypotéz, na jejichž základě by bylo možné modelovat nové logické struktury a ukazovat tak známé, nové či skryté souvislosti.
\end{abstract}

Klíčová slova: konstruktivismus, kognitivní procesy, analyticko-syntetický model, logická struktura, nadaný žák, trendy ve vzdělávání

\begin{abstract}
The support for the cognitive processes of gifted pupils is closely linked with the quality of pedagogical work in practice and it is determinate by the level of undergraduate training of future teachers. My contribution is focused mainly on defining the differences between the ways of gifted pupils' learning and the ways of traditional pupils' learning and on the analysis of the ways of gifted pupils' learning with regard to trends in constructivist pedagogy. Along with other cognitive agents this journey ends with the creation of the theory of education for gifted pupils for transfer into practice. The modernization of teaching methods can be based not only on improving existing strategies, but also on entirely new integral maps of individual disciplines which have been recognized worldwide. When designing the presented model, I tried to fulfil the vision that the new ideas should be transmitted systematically. They shall allow new research questions and formulation of such hypotheses under which it would be possible to model new logical structures and thus show well known, new or hidden connections.
\end{abstract}

Keywords: constructivism, cognitive processes, analytical-synthetic model, logical structure, gifted pupil, trends in education 


\section{1 Úvod}

Konstruktivismus je podle pedagogického slovníku vnímán jako: „Široký proud teorií ve vědách o chování a sociálních vědách, zdůrazňující jak aktivní úlohu subjektu a význam jeho vnitřních předpokladů $\mathrm{v}$ pedagogických a psychologických procesech, tak důležitost jeho interakce s prostředím a společností. V tom smyslu je také interakční teorií př́ekonávající jednostrannost empirismu a nativismu. V didaktice je jedním $\mathrm{z}$ dominantních soudobých paradigmat, dělících se do několika proudů“ (Průcha, Walterová, \& Mareš, 2001). Pro potřeby tohoto článku jsou zásadní tři proudy, kterými jsou kognitivní konstruktivismus, sociální konstruktivismus a jejich elektická syntéza. Následující modely nabízí logické struktury v analyticko-syntetickém pojetí, které jsou zaměřeny na rozvoj kognitivních procesů nadaného žáka v konstruktivistickém rámci. Sociální konstruktivismus zahrnuje soubor sociálně podmíněných pohnutek, postojů a přesvědčení žáka, budovaných a formovaných v edukačním procesu. Kognitivní konstruktivismus zahrnuje schopnosti žáků konstruovat logické struktury poznatků a identifikovat a interpretovat jejich obsah. Syntéza obou proudů je pak dokonalým vyjádřením potřeb nadaných žáků a představuje ve výuce prosazování řešení problémů ze života, tvořivé myšlení, práci ve skupinách a zejména méně teorie a drilu.

Konstruktivismus v pedagogickém pojetí definoval také např. Rudolf Kohoutek (profesor Masarykovy univerzity $\mathrm{v}$ Brně) jako „...podněcování učících se $\mathrm{k}$ interaktivitě, sociální komunikaci a k tvorbě vlastních poznatků, poznatkových struktur a ke kritickému posuzování informací, přechod od „tebeučení" (transmisivního vyučování) k „sebeučení", sebeiniciaci, sebeorganizaci a sebeevaluaci.“ K důležitým oblastem, které ovlivňují rozvoj kognitivních procesů nadaných žáků, řadím zejména pregraduální př́ípravu učitelů, graduované pedagogy na základních a středních školách a pedagogicko-psychologické poradny, které jsou organicky začleněny do následujícího modelu. Spolu s ostatními jeho činitely celá tato poznávací cesta končí vytvořením teorie vzdělávání nadaných žáků pro přenos do praxe. Evropským, ale také světovým trendem, se stává modelování logických struktur řady disciplín. Tento trend zasahuje také do oblasti pedagogiky. Cílem tohoto modelování je nabízet žákům ucelenou strukturu poznatků, které mohou akceptovat v rámci logického systému konkrétní vědy bez jejich nezbytného zjednodušení.

\section{Obecné pojetí analyticko-syntetického modelování}

Schéma reprezentuje obecné vstupy, které jsou nutné pro základní porozumění analytickosyntetickému modelování kognitivních struktur.

\subsection{Legenda ke schématu}

\footnotetext{
a ... (Identifikace komplexniho problému) - Zjišt'ovaný rozsah reality, zjišt'ovaný fenomén

$\mathbf{B}_{\mathbf{k}} \ldots$ (Analýza) - Analytické vytýčení rámce odpovídající znalostní hladině

$\mathbf{b}_{\mathbf{k}} \quad \ldots$ (Dílči problémy $P P-k$ ) - Výsledky analýzy: podstatné atributy a rysy zjišt'ovaného fenoménu

$\mathbf{C}_{\mathbf{k}} \ldots$ (Abstrakce) - Způsobilost abstrahovat úseky uvnitř rámce odpovídajícího znalostní hladině

$\mathbf{c}_{\mathbf{k}} \quad \ldots$ (Dílči řešení problémi̊ $P P-k$ ) - Výsledky abstrakce: dílčí koncepty, dílčí vědomosti, variantní souvislosti atp.

$\mathbf{D}_{\mathbf{k}} \quad \ldots$ (Syntéza) - Syntetické nalézání závislostí včetně výsledků abstrakce uvnitř rámce odpovídajícího znalostní hladině

$\mathbf{d}_{\mathbf{k}} \quad \ldots$ (Dílči závěry $P C-k$ ) - Výsledky syntézy: principy, zákony, vztahy, souvislosti, atp.

$\mathbf{E}_{\mathbf{k}}$... (Intelektuální rekonstrukce) - Intelektuální rekonstrukce zjišt’ovaných fenoménů/ zjišt'ovaného rozsahu reality

e ... (Úplné řešení komplexního problému "a") - Výsledky intelektuální rekonstrukce: analyticko syntetická struktura pojmového vědomostního systému
} 


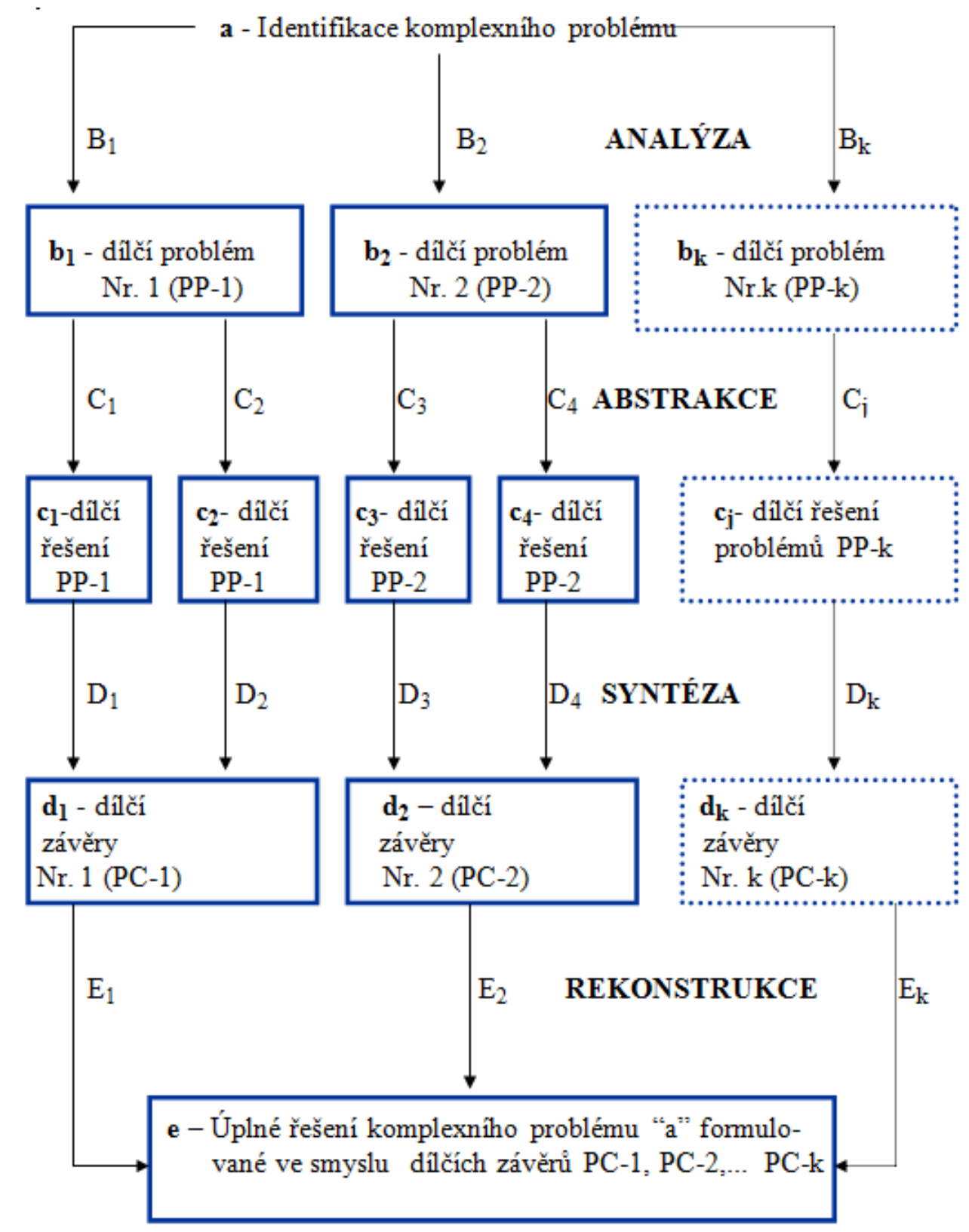

Obrázek 1. Obecný analyticko-syntetický model

\section{Model konstruktivistického př́stupu k systému vzdělávání nadaných žáků}

Model zahajuje analytické rozčlenění konstruktivismu jako určujícího trendu v pedagogice na dílčí jevy a objekty $\left(b, b_{1}, b_{2}, b_{3}\right)$ a vymezuje relace mezi nimi, které jsou označeny písmenem B. Pro naše potřeby interpretuji uvedené dílčí jevy a objekty jako systematizovanou př́pravu zainteresované skupiny pedagogů, podílejících se na vzdělávání nadaných žáků (objekty $c_{1} c_{2} c_{3} c_{4}$ a jejich vzájemná relace $\mathrm{C}$ ), $\mathrm{k}$ nimž směřuje vstupní univerzum. 


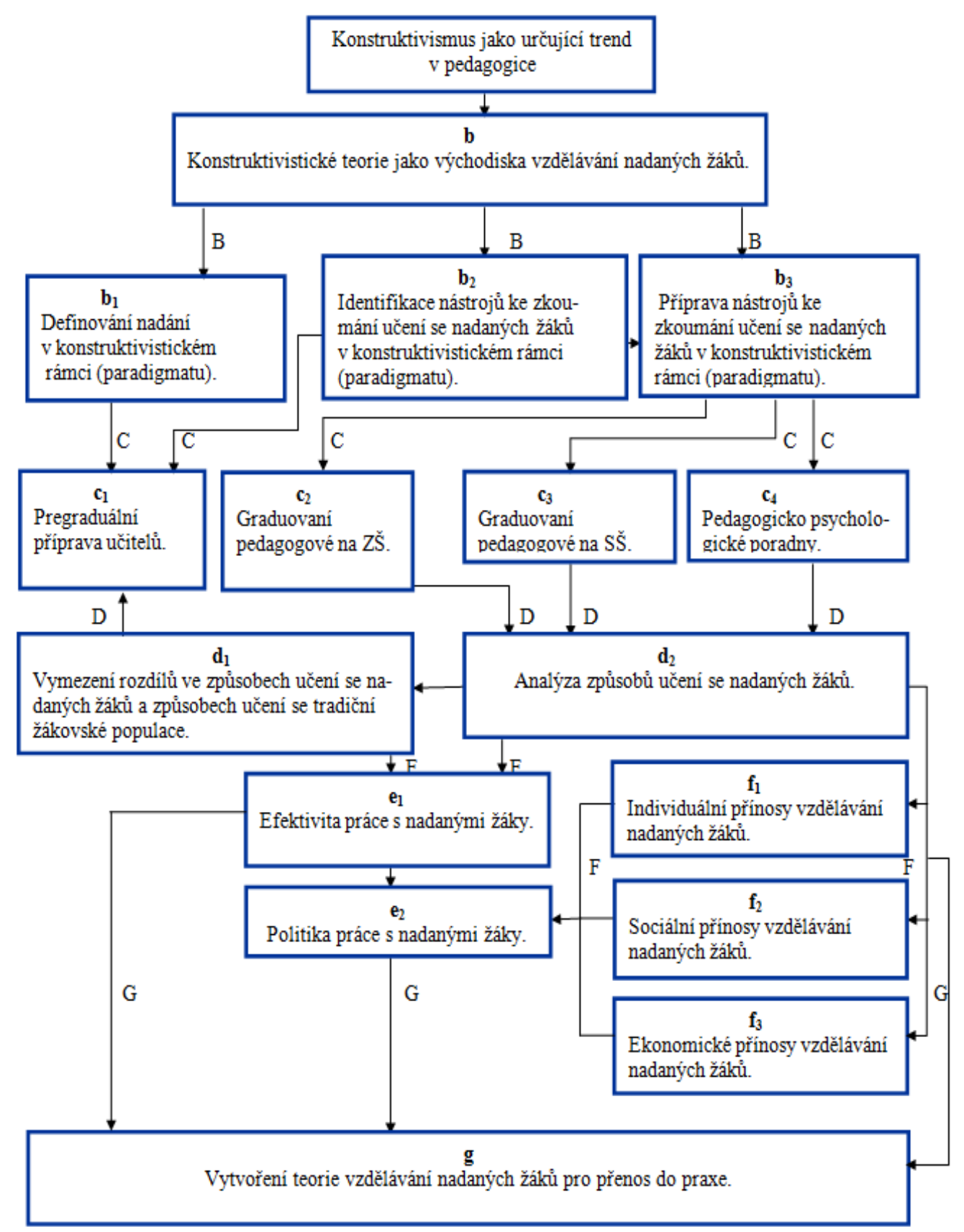

Obrázek 2. Model konstruktivistického př́istupu ke vzdělávání nadaných žáků

Relace mezi oblastmi b a oblastmi c jsou označeny písmenem C. Vymezováním vazeb mezi prvky $c_{1}, c_{2}, c_{3}$ a $c_{4}$ lze logickou cestou dospět k zákonitostem a vztahům $\mathrm{d}_{1} \mathrm{a} \mathrm{d}_{2}$ (relace mezi nimi jsou označeny písmenem D).

Následuje dílčí analytické rozčlenění oblastí $\mathrm{d}_{1}$ a $\mathrm{d}_{2}$ na oblasti e a f. Relace mezi nimi jsou označeny písmeny E a F.

Vymezováním vazeb mezi prvky e a f lze syntetickou cestou dospět $\mathrm{k}$ finále tohoto modelu, který končí vymezením obsahu a rozsahu cílového pojmu g. Ten představuje myšlenkovou reprodukci zkoumaného vstupního univerza.

Relace mezi objektem b (konstruktivistickými teoriemi jako východisky vzdělávání nadaných žáků) a objekty $b_{1}, b_{2}, b_{3}$ jsem označila písmenem B. Jedná se tedy o poznání, že edukační proces nadaného žáka představuje jak specifický komplex činitelů a vzájemně se 
ovlivňujících komponentů, které vytvářejí pro nadaného žáka celkovou intenzívní vzdělávací situaci, tak syntézu procesů identifikace a prŕípravy nástrojů ke zkoumání učení se nadaných žáků v konstruktivistickém rámci (paradigmatu).

V logické struktuře cílového pojmu g můžeme vysledovat určitou hierarchizaci v uspořádání skupin pojmů. Pojmy skupiny $\mathrm{b}, \mathrm{b}_{1}, \mathrm{~b}_{2}, \mathrm{~b}_{3}$ lze zařadit do vstupní (realitní) pojmové roviny, $\mathrm{c}_{1}$, $c_{2}, c_{3}, c_{4}, d_{1} a d_{2}$ do roviny analytické, dále uváděné pojmy $e_{1}, e_{2}$ do roviny abstraktní, $f_{1}, f_{2}, f_{3}$ do roviny syntetické a $g$ do cílové roviny pojmů.

Provedení deduktivní projekce logické struktury cílového pojmu na konkrétní specifikum umožňuje získávat aplikační pojmy, které lze považovat za prvky aplikační pojmové roviny.

$\mathrm{V}$ tomto prŕpadě vnímám jako součást aplikační pojmové roviny to, že dojde $\mathrm{k}$ vytvoření teorie vzdělávání nadaných žáků pro přenos do praxe.

Problematika práce s nadanými žáky se stále více dostává do povědomí pedagogické veřejnosti a tím se mění také postavení nadaných žáků v celém procesu jejich vzdělávání. Je potěšující, že reformní snahy v současném českém školství zohledňují prostřednictvím RVP ZV přítomnost nadaných žáků ve školách a nabízí tak učitelům možnosti aktivně a kreativně pracovat s těmito žáky. Rozhodla jsem se proto vytvořit analyticko-syntetický model edukačního procesu pro nadaného žáka, ve kterém nabízím pohled na vzdělávání nadaných žáků v globálním pojetí. Usiluji však také o analýzu základních potřeb nadaného žáka v současné škole a poukazuji na nutnost propojení všech činitelů, participujících na vzdělávání žáků. Tento model by měl umožnit určit navzájem interagující subsystémy pro výuku nadaných žáků v souvislosti se získáváním a rozvojem aktuálních souborů jejich klíčových kompetencí. Klíčovými kompetencemi zamýšlím kompetence, které jsou popsány v RVP ZV jako soubory vědomostí, dovedností, schopností postojů a hodnot důležitých pro osobní rozvoj jedince, jeho aktivní zapojení do společnosti a budoucí uplatnění v životě. V etapě základního vzdělávání jsou za klíčové považovány:

\footnotetext{
$>\quad$ kompetence $\mathrm{k}$ učení

$>\quad$ kompetence $\mathrm{k}$ řešení problémů

$>\quad$ kompetence komunikativní

$>\quad$ kompetence sociální a personální

$>\quad$ kompetence občanské

$>\quad$ kompetence pracovní.
}

\section{Model logické struktury edukačního procesu pro nadaného žáka}

Zobrazení vymezené logické struktury (graf na obrázku 3) edukačního procesu pro nadaného žáka orientovaným grafem lze popsat takto: následující schéma vystihuje v rámci deduktivního př́stupu pouze globální zařazení poznávacího procesu nadaného žáka do didaktického systému na českých školách. Vycházím z vymezování vstupního univerza $\mathrm{a}_{1}$, které lze pro naše potřeby popsat jako oblast, ve které nadaní žáci získávají klíčové kompetence, popsané v RVP ZV. Pak následuje analytické rozčlenění na dílčí jevy a objekty $\left(b_{1}, b_{2}, b_{3}, b_{4}\right)$ a vymezení relací mezi nimi, které jsou označeny písmenem B. Pro naše potřeby interpretuji uvedené dílčí jevy a objekty jako soubory kompetencí, k nimž směřuje vstupní univerzum a soubory didaktických forem a metod, kterými jsou tyto kategorie realizovány. Oblast $b_{4}$ je ovšem podmíněna nejen intelektuálními možnostmi nadaných žáků, ale zejména jejich osobnostními vlastnostmi. 
$a_{1}$

Vzděláváni nadaných žákủ jako specifický proces předáváni poznatkủ a metod vědeckého poznávání, který se realizuje v intencích společenských zájmủ a potřeb

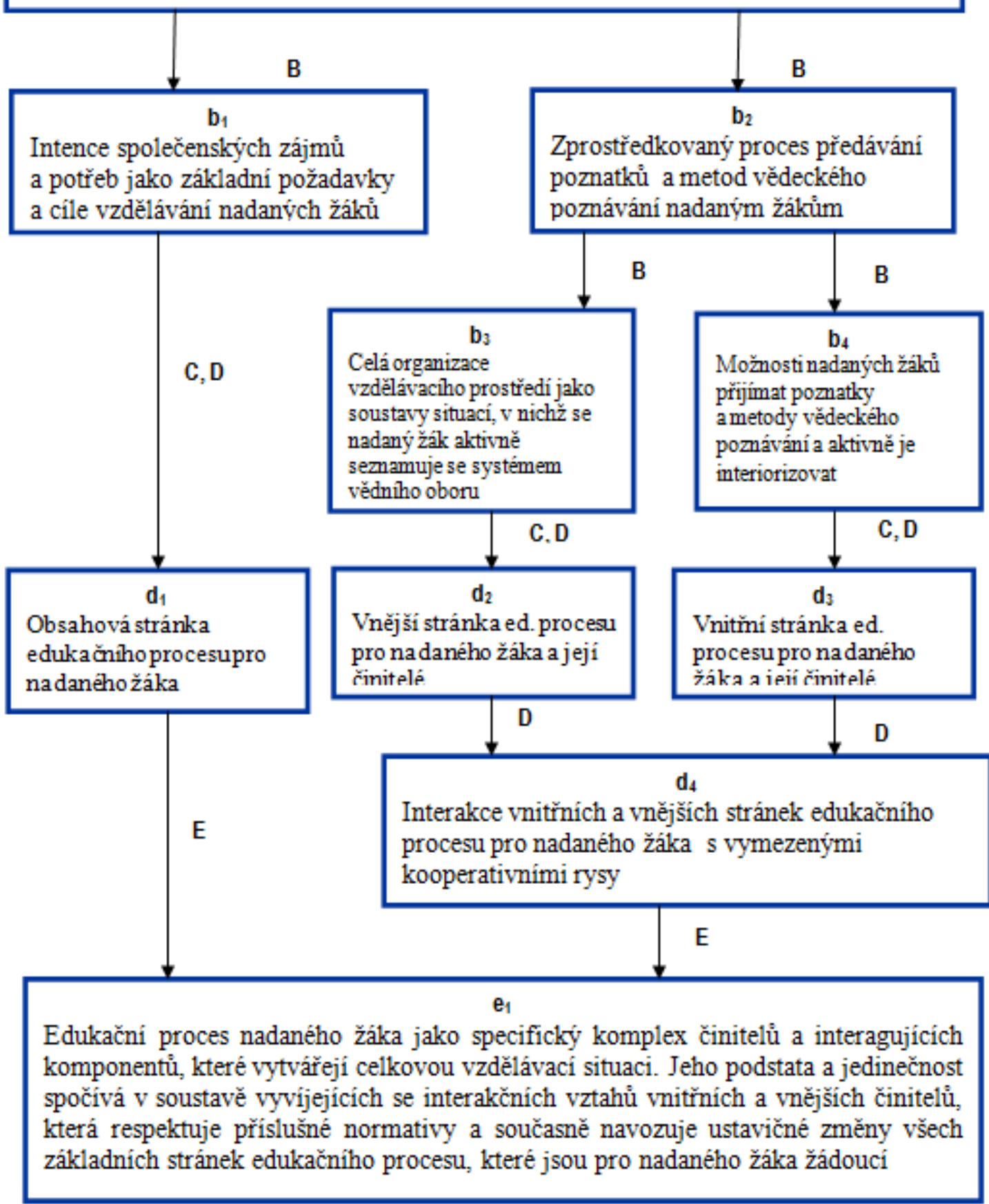

Obrázek 3. Model logické struktury edukačního procesu pro nadaného žáka

Relace mezi oblastmi b a oblastmi c jsou označeny písmenem C. Vymezováním vazeb mezi prvky $c_{1}, c_{2}, a c_{3}$ lze syntetickou cestou dospět $\mathrm{k}$ zákonitostem a vztahům $\mathrm{d}_{1}, \mathrm{~d}_{2}, \mathrm{~d}_{3}, \mathrm{~d}_{4}$ (relace mezi nimi jsou označeny písmenem $\mathrm{D}$ ).

- $\mathrm{d}_{1}$..obsahovou stránkou edukačního procesu pro nadaného žáka zamýšlím v podstatě veškerou náplň jednotlivých předmětů, které v rámci své školní docházky žák absolvuje 
- $\mathrm{d}_{2} \ldots$ skupina vnějších činitelů edukačního procesu pro nadaného žáka zahrnuje řízení a organizaci výchovně-vzdělávacích institucí a jejich materiální zabezpečení, učitele a jejich další vzdělávání, metody a formy edukačních aktivit, materiální a nemateriální didaktické prostředky a také výběr, organizaci a uplatnění vhodných vyučovacích metod

- $\mathrm{d}_{3} \ldots$ skupina vnitřních činitelů edukačního procesu pro nadaného žáka zahrnuje pohnutky, postoje a přesvědčení takového jedince ve vztahu k vlastnímu vzdělávání a k získávání klíčových kompetencí

- $\mathrm{d}_{4}$...interakcí vnitřních a vnějších stránek edukačního procesu s vymezenými kooperativními rysy mám na mysli vzájemné horizontální propojení definovaných činitelů a jejich následnou interaktivní spolupráci a vzájemné dotváření konkrétních didaktických situací pro nadaného žáka

V logické struktuře cílového pojmu $e_{1}$ můžeme vysledovat určitou hierarchizaci v uspořádání skupin pojmů. Pojmy skupiny $\mathrm{a}_{1}$ lze zařadit do vstupní (realitní) pojmové roviny, $\mathrm{b}_{1}-\mathrm{b}_{4}$ do roviny analytické, dále uváděné pojmy $\mathrm{c}_{1}-\mathrm{c}_{14}$ do roviny abstraktní, $\mathrm{d}_{1}-\mathrm{d}_{4}$ do roviny syntetické a $\mathrm{e}_{1}$ do cílové roviny pojmů.

Provedení deduktivní projekce logické struktury cílového pojmu na konkrétní specifikum umožňuje získávat aplikační pojmy, které lze považovat za prvky aplikační pojmové roviny. V našem případě vnímám jako součást aplikační pojmové roviny to, že nadaný žák získá soubor klíčových kompetencí, které jsou výsledkem správného fungování specifického komplexu činitelů a dalších komponentů, vytvářejících jeho celkovou vzdělávací situaci. Celá tato poznávací cesta končí vymezením obsahu a rozsahu cílového pojmu $\mathrm{e}_{1}$, který představuje myšlenkovou reprodukci zkoumaného vstupního univerza (relace mezi objekty $\mathrm{d}_{1}-\mathrm{d}_{4}$ a objektem $e_{1}$ jsem označila písmenem E). Jedná se tedy o poznání, že edukační proces nadaného žáka představuje specifický komplex činitelů a vzájemně se ovlivňujících komponentů, které vytvářejí pro nadaného žáka celkovou intenzívní vzdělávací situaci. Podstata a jedinečnost tohoto poznání spočívá v soustavě dynamicky se vyvíjejících interakčních vztahů vnitřních a vnějších činitelů, která respektuje př́slušné normativy a současně navozuje ustavičné změny všech základních stránek edukačního procesu, které jsou pro nadaného žáka žádoucí.

Tento př́spěvek nabízí k posouzení a případné komparaci atraktivní modelování logických struktur na různých úrovních na jedné straně a tradiční, i když inovované postupy zpracování a transformace vědeckých poznatků na straně druhé. Modernizace učebních postupů může být založena nejen na zdokonalování stávajících strategií, ale také na zcela nových, ve světě již popsaných integrálních mapách jednotlivých disciplín. Závěrem považuji za důležité konstatovat, že jsem se při konstruování těchto modelů snažila naplnit vizi, že nová sdělení mají být předávána systematicky, přehledně, úsporně a elegantně. Mají umožňovat kladení nových výzkumných otázek a formulování takových hypotéz, na jejichž základě by bylo možné modelovat nové logické struktury a ukazovat tak známé, nové či skryté souvislosti.

\section{Literatura}

Průcha, J., Walterová, E., \& Mareš, J. (2001). Pedagogický slovník. Praha: Portál.

Škrabánková, J. (2009). A model of the logical structure of the educational process for a gifted student. In Education end Talent 3 (pp. 10-18). Brno: PdF MU.

Záškodný, P., \& Tarábek, P. (2002). Didactic communication and educational sciences. In Brochure of Conference "Analytical - synthetic modelling of cognitive structures, New York“. Bratislava: Educational Publisher Didaktis Ltd. 


\section{Kontakt}

Doc. PaedDr. Jana Škrabánková, Ph.D.

Ostravská univerzita

Pedagogická fakulta, Katedra pedagogiky a andragogiky

Fráni Šrámka 3, 70900 Ostrava

e-mail: jana.skrabankova@osu.cz

\section{Bibliografické údaje}

Škrabánková, J. (2011). Podpora kognitivních procesů nadaných žáků v konstruktivistickém pojetí. In T. Janík, P. Knecht, \& S. Šebestová (Eds.), Smíšený design v pedagogickém výzkumu: Sborník př́spěvků z 19. výročni konference České asociace pedagogického výzkumu (s. 215-222). Brno: Masarykova univerzita.

Dostupné z: http://www.ped.muni.cz/capv2011/sbornikprispevku/skrabankova.pdf doi: 10.5817/PdF.P210-CAPV-2012-60 